\title{
Life Cycle Assessment of Geotechnical Works in Building Construction: A Review and Recommendations
}

\author{
Xingqiang Song *(D), Christel Carlsson, Ramona Kiilsgaard, David Bendz and Helene Kennedy \\ Swedish Geotechnical Institute, Olaus Magnus väg 35, 58193 Linköping, Sweden; \\ christel.carlsson@swedgeo.se (C.C.); ramona.kiilsgaard@swedgeo.se (R.K.); david.bendz@swedgeo.se (D.B.); \\ helene.kennedy@swedgeo.se (H.K.) \\ * Correspondence: xingqiang.song@swedgeo.se; Tel.: +46-13-201807
}

Received: 27 August 2020; Accepted: 8 October 2020; Published: 13 October 2020

\begin{abstract}
Life cycle assessment (LCA) is becoming an increasingly important environmental systems analysis tool in the construction sector for the identification of measures and strategies to reduce the environmental impact of buildings throughout the whole value chain. Geotechnical processes, such as earthworks, ground improvement and foundation construction, are often energy- and resource-intensive. Geotechnical works can thus play an important role in moving towards more sustainable building construction practices. This article reviews recent applications of LCA of buildings, including foundations as the focus or part of the system studied, based on the ISO 14040/44 standards. The system boundaries of geotechnical works are defined and a conceptual model for LCA of geotechnical works in building construction is proposed. The results of the literature review showed that the application of LCA to the building substructure is currently under development, but still in a fragmented state. There is a need for a unified framework for LCA of geotechnical works in building construction, especially regarding the definition of the functional unit, the choice of system boundaries, the appropriateness of inventory data, and the selection of impact categories. The conceptual model focuses on the demonstration of inventory flows and system boundaries and can serve as a basis for scope definition in future LCA studies of geotechnical works in building construction. It may also support effective communication between different actors and stakeholders regarding environmental sustainability in the construction sector.
\end{abstract}

Keywords: life cycle assessment; building; construction; foundation; sustainability

\section{Introduction}

The building and construction sector is one of the key components in the transition to a resource-effective and climate-neutral society. Within the European Union (EU), buildings account for the largest share of the total amount of extracted materials (50\%) and final energy consumption $(42 \%)$, and cause about $35 \%$ of all greenhouse gas (GHG) emissions [1]. In 2011, the EU endorsed an objective to decrease GHG emissions from the building sector by around $90 \%$ by 2050 , compared to 1990 [2]. In 2018, the EU presented a climate-neutral vision for achieving net-zero GHG economy by 2050, in which two of the seven main strategic building blocks were: to maximize the benefits of energy efficiency including zero emission buildings, and to establish a competitive industry and circular economy to enable the reduction of GHG emissions [3]. In December 2019, the European Council endorsed the objective of making the EU climate-neutral by 2050, in line with the Paris Agreement [4]. A new climate policy framework was adopted in Sweden in 2017, with a long-term target of net zero emissions of GHGs into the atmosphere by 2045 [5]. In 2018, the Swedish construction and civil 
engineering sector presented a roadmap for fossil-free competitiveness, which emphasized the roles of technological shifts, innovation and a life-cycle perspective, to support Sweden's climate goals [6]. In the pursuit of climate-neutral and sustainable buildings, life cycle thinking and life cycle assessment are expected to play a vital role in understanding and assessing the environmental performance of all the stages of a building's life cycle in a broader systems perspective.

Life cycle assessment (LCA) is an internationally standardized method of assessing the potential environmental impact of a product or service throughout its entire life (i.e., from raw material extraction, manufacturing, production and product use, to the end of the product's life) $[7,8]$. Apart from the ISO standard 14040 series governing LCA, there are standards and guidelines for LCA of buildings and civil engineering works. For instance, the European Committee for Standardization has developed a series of standards for the assessment of the sustainability of buildings [9] using a life cycle approach, among which EN 15978 (on the environmental performance of buildings) and EN 15804 (on environmental product declarations for all construction products and materials) are applicable for LCA of buildings and construction works.

In recent years, there is a growing body of literature that recognizes the need for a wide application of LCA as a method to assess the environmental impacts of buildings [10]. Traditionally, the focus of most studies has been on the environmental analysis of the operational/usage phase of buildings in relation to operational energy use [11-15]. Owing to improvements in building energy efficiency, it has been predicted that the relative contribution of the construction phase to the total environmental burden will increase [16,17]. Recent publications presenting LCA of buildings devote considerable attention to investigating the environmental performance of the construction phase in detail, for example, building structure [18,19], construction materials [20-23], GHG emissions from construction processes [24,25], embedded energy [26,27] and the carbon footprint of buildings [28,29]. However, a number of challenges remain in the application of LCA to buildings, due to both the complexity of building systems (such as a long lifespan, location-specific conditions, and diverse building materials) [14,30], and LCA methodological aspects (such as intensive data demand, choice of impact categories and level of transparency) [31].

LCA has been applied to the construction and civil engineering sector for over a decade. In the civil engineering sector, for instance, LCA-based case studies have been carried out on retaining wall structures [32-34], ground improvement works [35,36], soil stabilization [37], excavation on construction sites [38], etc. As regards LCAs conducted for building construction, most studies tend to focus on construction of building foundations, such as sustainability indicators for pile foundations [39], sustainability assessment of deep foundations for high-rise buildings [40], and the global warming potential of pile foundation construction [41]. Until now, however, no literature reviews have been published with focus on applications of LCA to geotechnical construction works for buildings.

Geotechnical processes take place at the early stage of the life cycle of a building and are often energyand resource-intensive. Geotechnical works deserve more attention in improving the environmental performance of building construction [42] in a life cycle perspective. Nowadays the practices prevailing in the construction and civil engineering sectors are based largely on traditional factors, such as financial cost, regulatory compliance, technical performance, and safety, while sustainability and life cycle thinking are rarely taken into consideration [43]. In a recent review of life-cycle-based environmental assessments of geotechnical systems [44], a shift in conventional geotechnical practice was emphasized, underlining the need for efforts in LCA data collection, the development of LCA criteria, and the establishment of practical LCA methods. In fact, few researchers have addressed the whole process of geotechnical works in LCAs of building construction.

In an attempt to fill the gaps identified above, this article reviews recent applications of LCA in buildings, including foundations as the focus or part of the system studied, based on ISO 14040/44 standards. Furthermore, the objectives are to define the system boundaries of geotechnical works and develop a conceptual model, intended to support scope definition in future LCA studies on geotechnical works in building construction. 


\section{Materials and Methods}

\subsection{LCA Standards and Terminology Referred to in the Present Study}

The LCA standards referred to in the present study include the international standards ISO 14040:2006 [7] and ISO 14044:2006 [8] for the LCA methodology, and the European standard EN 15978:2011 [45] for the assessment of the environmental performance of buildings. To provide a better understanding of the various system boundaries used in the literature on building LCAs, the links between different types of system boundaries for LCA in general, and the stages of a building life cycle specifically, are illustrated in Figure 1.

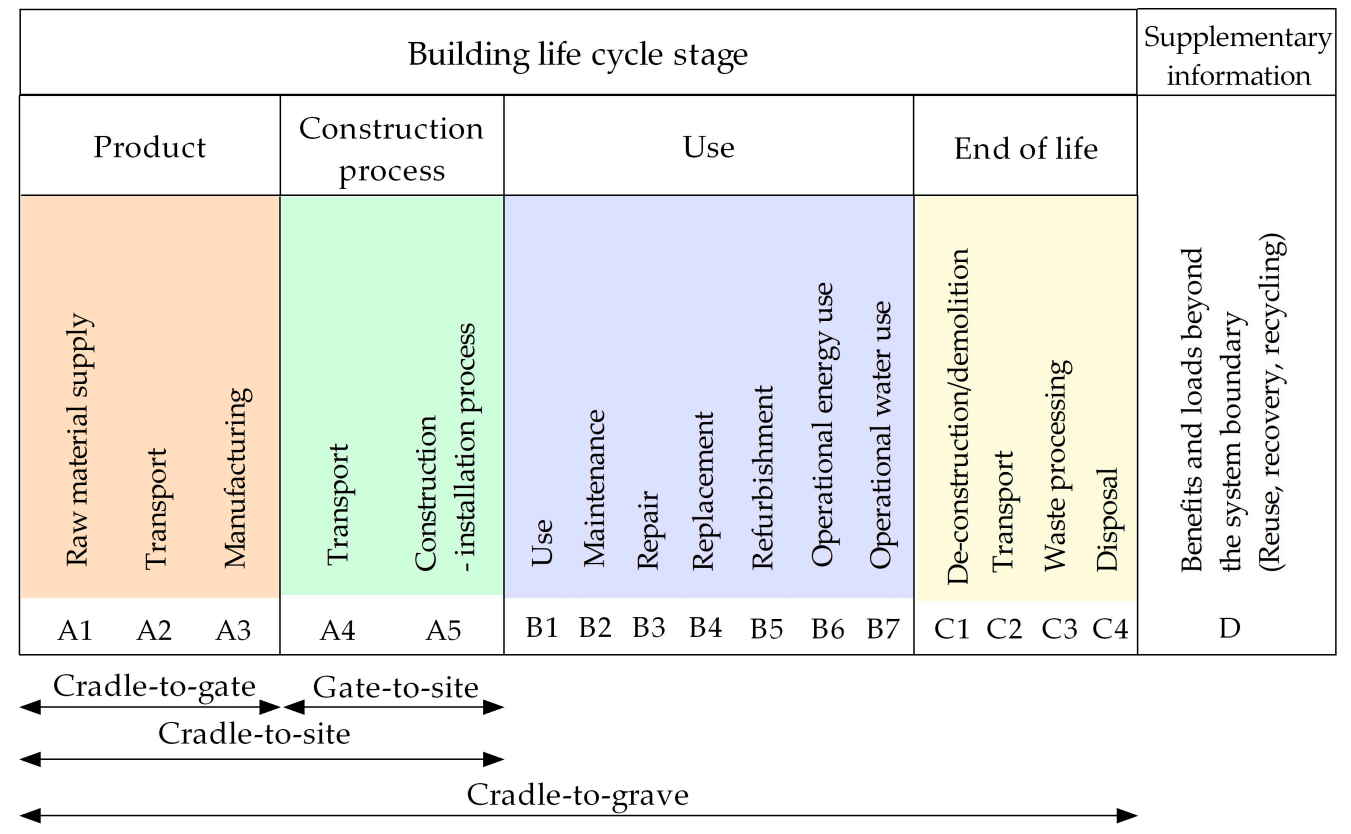

Figure 1. Links between the stages in a building's life cycle and LCA-related system boundaries (modified from EN 15978:2011).

As defined in ISO 14040, there are four interrelated phases in an LCA study: (i) goal and scope definition, (ii) life cycle inventory analysis (LCI), (iii) life cycle impact assessment (LCIA), and (iv) interpretation. In theory, the LCA methodology represents a common type of cradle-to-grave system boundary. The system boundary can also be defined as part of the life cycle, for example, cradle-to-gate, gate-to-gate or gate-to-grave, when performing a partial LCA study. Similarly, the EN 15978 standard describes four building life cycle stages, including (i) the product stage (modules A1-A3: from raw material supply to manufacturing), (ii) the construction process stage (module A4: transport to building site, and module A5: on-site construction), (iii) the use stage (modules B1-B7: use, maintenance, repair, replacement, refurbishment, and operational energy and water use), and (iv) the end of life stage (modules C1-C4: from de-construction, waste processing, to final disposal). Throughout this study, the term cradle-to-gate refers to the product stage (modules A1-A3), gate-to-site refers to the construction process stage (modules A4-A5), cradle-to-site refers to the product and construction process stages (modules A1-A5, sometimes called the pre-use phase), and cradle-to-grave to all the stages of the building's life cycle (modules A1-C4).

\subsection{Conceptualisation of Geotechnical Works in Building Construction}

Geotechnical engineering activities, including ground investigation, geotechnical design and construction work [46,47], constitute an important part of building construction projects. Based on Eurocode 7 [48], which regulates geotechnical design in Europe, representative geotechnical construction 
works for buildings include: (i) the earth structure (civil engineering structure, consisting of filling material or as a result of excavation), (ii) the retaining structure (the structure that provides lateral support to the ground or that resists pressure from the mass of other materials), (iii) the foundation (construction for transmitting forces to the supporting ground, by means of shallow, deep or hybrid foundations), and (iv) the ground improvement zone (the volume of ground in which ground improvement systems are installed, which results in modified ground properties). Examples of other common terms used to describe geotechnical works, as defined in Eurocode 7 [48], are:

- Earthworks, a civil engineering process that modifies the geometry of the ground surface, by creating stable and durable earth structures;

- Ground improvement, modification of the ground or its hydraulic conductivity in order to bring the effects of actions within ultimate and serviceability requirements.

Figure 2 illustrates the system boundary of geotechnical works in building construction. In principle, all geotechnical works should be considered when defining the system boundary for assessment of the environmental performance of building construction. It should be noted that temporary geotechnical works, such as temporary excavation support for deep excavations, are not shown in Figure 2. Moreover, the basement and the ground slab are not included in the geotechnical system. In a site-specific case study, the design of foundations and the need for ground improvement depend on the local geological conditions and the design load.

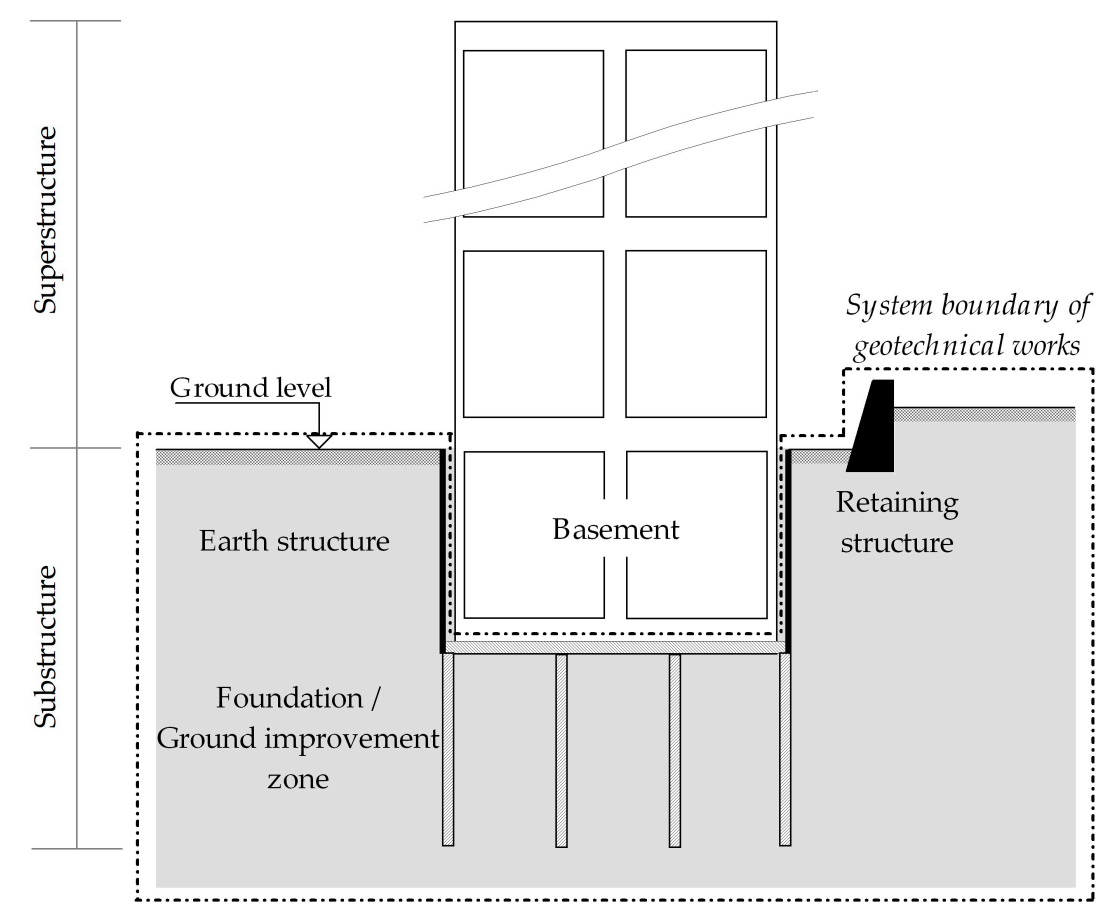

Figure 2. Schematic illustration of the system boundary for geotechnical works associated with building construction.

According to ISO 6707-1:2017 [49], the substructure and superstructure are the two major parts of a building. In addition, the term "basement" is defined as "the usable part of a building, situated partly or entirely below ground level".

\subsection{Scope of the Literature Review}

Two criteria were employed in the literature search and to assess the relevance of the retrieved articles. First, the scope of the literature search was limited to building LCA studies reported in English 
and published in peer-reviewed scientific journals in the past five years (accessed on 15 May 2020). The Web of Science platform was used for literature searching using the following search terms: "life cycle assessment" and/or "LCA" and/or "building" and/or "construction" and/or "foundations" and/or "emissions" and/or "geotechnical". The retrieved articles were then assessed to determine whether the studies involved building foundations (materials and/or on-site construction activities), either as the focus or as part of the system studied, in both life cycle inventory analysis and impact assessment phases.

Using these literature selection criteria, twelve articles were identified for review in further detail, including six studies focusing on building foundations, five on the construction phase (and/or construction-oriented product), and one on the building's total life cycle (Table 1). The assessment of these twelve articles, with varying system boundaries, is intended to provide an overarching picture of the most recent application of LCA to the construction of building substructures. The aim was to present results useful for communication about sustainable building construction and geotechnical works between stakeholders (e.g., LCA practitioners, geotechnical engineers, foundation designers and contractors), and to facilitate the broader application of LCA results at different levels of planning and decision-making.

\subsection{Key LCA Elements Reviewed}

The twelve articles were reviewed from the LCA methodology perspective, based on the ISO standards 14040/14044. The following key LCA elements were addressed in the present study:

- System boundaries

- Functional unit

- Inventory data sources and quality

- Life cycle impact assessment

- Interpretation

System boundaries and the functional unit are important elements in defining the goal and scope of an LCA study. The system boundary determines which life cycle stages, unit processes, inflows and outflows are to be included (or excluded) within a specific LCA study. As specified in the ISO 14044 standard, the definition of system boundary should be consistent with the goal of the study, and the criteria used to define the system boundary should be identified and explained in the goal and scope definition phase. The functional unit must be relevant and correctly defined, which is the basis for comparison of different systems. The choice of functional unit can substantially influence the results of LCI and LCIA, as well as the interpretation of LCA results [50].

The availability and quality of LCI data are fundamental issues in all LCA studies. Data availability is important as it determines the level of detail of an LCA study [51]. Data quality includes the completeness of the inventory, the accuracy (representativeness (technological, geographical and time-related), methodological appropriateness and consistency), and precision/uncertainty [52].

The aim of the LCIA phase is to assess the potential environmental impact of the environmental loads quantified in the LCI phase. To date, a variety of impact assessment methods have been developed. The choice of impact assessment method may affect the results of an LCA study, due to differences in the impact categories considered, and in the approaches used to model environmental mechanisms.

Interpretation is the final phase of an LCA, which consists of three main elements: (i) identification of the significant issues based on the results of LCI and LCIA, (ii) evaluation by completeness, sensitivity, and consistency checks, and (iii) conclusions, limitations, and recommendations [8]. The data- and assumption-related uncertainties of LCA results should also be analysed and documented. The sensitivity check is intended to determine how the results are affected by various uncertainties, for example, in the LCI data and the calculation of category indicator results [8]. 
Table 1. Summary of the twelve articles reviewed.

\begin{tabular}{|c|c|c|c|c|c|c|c|c|}
\hline \multicolumn{4}{|c|}{ General } & \multirow[b]{2}{*}{ System Boundary } & \multirow[b]{2}{*}{$\begin{array}{l}\text { Geotechnical } \\
\text { Works Included }\end{array}$} & \multirow[b]{2}{*}{ Functional Unit } & \multirow[b]{2}{*}{$\begin{array}{l}\text { Background Data } \\
\text { Sources }\end{array}$} & \multirow[b]{2}{*}{ Reference } \\
\hline $\begin{array}{l}\text { Building } \\
\text { Type }\end{array}$ & $\begin{array}{l}\text { Building } \\
\text { Location }\end{array}$ & $\begin{array}{l}\text { Life Span } \\
\text { (Years) }\end{array}$ & $\begin{array}{c}\text { Year } \\
\text { Published }\end{array}$ & & & & & \\
\hline Residential & Brazil & 50 & 2018 & $\begin{array}{l}\text { Cradle-to-grave } \\
\text { (all life cycle stages) }\end{array}$ & N/A & $1 \mathrm{~m}^{2}$ of total built-up area & Ecoinvent v3.0 & [53] \\
\hline Residential & Finland & $\mathrm{N} / \mathrm{A}^{1}$ & 2016 & $\begin{array}{l}\text { Cradle-to-site } \\
\text { (pre-use phase) }\end{array}$ & EW & $1 \mathrm{~m}^{2}$ of gross floor area & Ecoinvent v2.0 & [54] \\
\hline Residential & Cyprus & 50 & 2017 & $\begin{array}{l}\text { Cradle-to-site } \\
\text { (pre-use phases) }\end{array}$ & N/A & $1 \mathrm{~m}^{2}$ of useful floor area & EcoHestia database & [55] \\
\hline Commercial & China & 50 & 2017 & $\begin{array}{l}\text { Cradle-to-site } \\
\text { (pre-use phase) }\end{array}$ & $\mathrm{EW}, \mathrm{FC}^{2}$ & $1 \mathrm{~m}^{2}$ of total construction area & Based on the literature & [56] \\
\hline Residential & $\begin{array}{c}\text { Sri } \\
\text { Lanka }\end{array}$ & 50 & 2018 & $\begin{array}{l}\text { Cradle-to-gate } \\
\text { (pre-use phase) }\end{array}$ & $\mathrm{N} / \mathrm{A}$ & $1 \mathrm{~m}^{2}$ of gross floor area & $\begin{array}{c}\text { ICE database v } 2.0^{3} \text { and } \\
\text { the literature }\end{array}$ & [57] \\
\hline Residential & Finland & N/A & 2019 & $\begin{array}{l}\text { Cradle-to-site } \\
\text { (pre-use phases) }\end{array}$ & N/A & $1 \mathrm{~m}^{2}$ of gross floor area & $\begin{array}{c}\text { Gabi database v6.1, } \\
\text { ecoinvent v3.0 }\end{array}$ & [58] \\
\hline Residential & Slovakia & N/A & 2016 & $\begin{array}{c}\text { Cradle-to-gate } \\
\text { (foundation materials) }\end{array}$ & N/A & $1 \mathrm{~m}^{2}$ of building floor area & IBO database & [59] \\
\hline Residential & Australia & N/A & 2016 & $\begin{array}{c}\text { Cradle-to-site } \\
\text { (foundation construction) }\end{array}$ & EW, FC & $\begin{array}{l}1 \mathrm{~m}^{2} \text { of total foundation area } \\
\text { (basement + ground floor) }\end{array}$ & $\begin{array}{l}\text { EF published by ICE, } \\
\text { AUS NIR and US EPA }^{3}\end{array}$ & {$[60]$} \\
\hline N/A & N/A & 50 & 2018 & $\begin{array}{l}\text { Cradle-to-site } \\
\text { (shallow foundations) }\end{array}$ & EW, FC & A concrete shallow foundation & Ecoinvent v3.3 & {$[61]$} \\
\hline $\begin{array}{l}\text { Hospital \& } \\
\text { residential }\end{array}$ & China & N/A & 2019 & $\begin{array}{c}\text { Cradle-to-site } \\
\text { (foundation construction) }\end{array}$ & EW, FC & $1 \mathrm{~m}^{2}$ of gross floor area & $\begin{array}{l}\mathrm{EF}^{3} \text { from a local } \\
\text { manufacturer }\end{array}$ & [62] \\
\hline Residential & Spain & 50 & 2020 & $\begin{array}{l}\text { Cradle-to-site } \\
\text { (deep foundations) }\end{array}$ & EW, FC & A concrete deep foundation & Ecoinvent v3.0 & [63] \\
\hline Office & China & N/A & 2020 & $\begin{array}{c}\text { Gate-to-site } \\
\text { (foundation construction) }\end{array}$ & $\mathrm{FC}$ & $1 \mathrm{~m}^{2}$ of total construction area & Based on the literature & {$[64]$} \\
\hline
\end{tabular}

1 "N/A" denotes that information is missing or not clearly described in the respective article. ${ }^{2}$ EW: Earthworks, FC: Foundation construction. ${ }^{3}$ ICE: Inventory of Carbon and Energy; EF: emission factors; AUS NIR: Australian National Inventory Report; US EPA: United States Environmental Protection Agency. 


\section{Results}

\subsection{System Boundaries}

Few of the reviewed articles had achieved a compromised balance between coverage of the various stages of the building's life cycle and the level of detail in geotechnical construction works. In the six articles including building foundations, either as part of the whole building life cycle analysis [53] or the construction stage [54-58], only limited information on building foundations was presented. In fact, most of them presented aggregated results for the total mass of foundation materials and their relative contribution to the overall impact of the system studied. In two articles, building foundations were combined with other building systems in LCI and LCIA, namely with floors [55] and external structures [54]. All six of these articles included materials for building foundations, while only two articles addressed geotechnical construction works, namely earthworks [54,56] and foundation construction [56].

Regarding the other six articles focusing on building foundations, there were notable differences in the definition of the goal and scope of the studies. In one article [59], apart from environmental analysis of the building's foundations, a comparison was made of the environmental impacts of the materials used for building foundations and the total building materials. Comparative LCAs of different types of building foundations were performed in two articles, i.e., (i) between pile and raft foundations for two different high-rise residential buildings [60], and (ii) between cast-in-situ pile foundation in a hospital building and precast pile foundation in a residential building [62]. Another two articles analysed the potential environmental impact of a shallow foundation [61] and a deep foundation [63], considering the influence of prefabrication, typology and structure design codes. In contrast to the other articles, these two articles $[61,63]$ also presented information on the geometry and parameter definition, as well as the geotechnical design of the foundations. Only one of these six articles [59] did not include geotechnical construction works. The other five [60-64] addressed foundation construction works, among which four [60-63] also included earthworks.

A total of four types of system boundaries were applied in the twelve articles. Specifically, eight articles employed the cradle-to-site boundary [54-56,58,60-63], two the cradle-to-gate boundary [57,59], one the cradle-to-grave boundary [53], and one the gate-to-site boundary [64]. However, the criteria used to define system boundaries were not clarified in all the articles. Taking the two articles employing the cradle-to-gate boundary as an example [57,59], neither explained why the transport vehicles and on-site use of machines were excluded from the study.

\subsection{Functional Unit}

The functional unit is used as a reference unit for the quantitative description of the identified function (performance characteristics) of a product or the product systems to be analysed [7]. The definition of the functional unit is a unique feature of LCA, distinguishing it from other environmental assessment approaches [65].

A variety of functional units were defined in the reviewed articles (Table 1). Four different functional units were defined in the six articles [53-58] on the building life cycle or the product/construction stages. Six different functional units were used in the six articles [59-64] focusing on building foundations. In particular, two articles [61,63] defined their respective functional units of CSF (concrete shallow foundation) and CDF (concrete deep foundation) from a foundation design perspective. In the article on CSF [61], for instance, the authors defined the functional unit as "an isolated shallow CSF that can withstand a $0.4 \times 0.4 \mathrm{~m}$ column with a dead load of $400 \mathrm{kN}$ and an imposed load of $150 \mathrm{kN}$, built on a silty soil with a bearing pressure of $150 \mathrm{kN} / \mathrm{m}^{2}$, without the presence of a water table, seismicity, or chemical action, and designed for a service life of 50 years". Furthermore, most of the articles reviewed lacked clear explanations of the functional units, making it difficult to distinguish differences between similar functional units, such as: (i) "total construction area" [64] and "total built-up area" [53], and (ii) "gross floor area" [54,57,58], "useful floor area" [55] 
and "building floor area" [59]. It is therefore difficult to compare the results from these LCA studies in a reliable way.

\subsection{Inventory Data Sources and Quality}

The background data were obtained from a variety of sources, namely existing databases, local manufacturers (through personal interviews by the authors), and the literature (Table 1). Three interesting features were noted in this context. Firstly, there was a lack of transparency in the details of unit processes used for LCA modelling in most studies. Regarding the five articles using the ecoinvent database, for instance, only one [63] provided a list of the chosen ecoinvent unit processes, without further information on these unit processes (such as time frame of the unit process data). In the other four articles $[53,54,58,61]$, the unit processes taken from the ecoinvent database were not specified. Secondly, most of the reviewed articles used data sources representing other geographical regions. For example, in the LCA of a residential building in Sri Lanka, the Inventory of Carbon and Energy (ICE) database, representing mostly the UK construction industry, was used [57]. Similarly, the study on environmental emissions from the foundation construction stage of two high-rise residential buildings in Australia was based on the ICE database to estimate the embodied emissions from materials, and the US EPA emission factors to estimate non-GHG emissions from on-site use of stationary equipment [60]. Thirdly, several articles (re)used data from the literature, without giving references to the original data sources [62,64], or further consideration of the representativeness and appropriateness of the literature data [56].

Regarding foreground data, all the reviewed articles presented the results of data collection in the LCI phase, although the level of detail varied in different studies. Seven articles [53-55,58,62-64] referred to the bill of quantities obtained from construction companies. Three articles $[56,57,59]$ lacked a clear description of data sources. In one article [61], calculations were made based on existing models and design codes. Surprisingly, only one of the twelve articles reported the year of completion of the building [58]. When performing LCA of geotechnical works for buildings, neglecting to provide information on the time of construction may lead to a failure to use time-representative background data as well as an increase in the uncertainty in the results of LCIA.

\subsection{Life Cycle Impact Assessment}

All twelve of the reviewed articles addressed at least one impact category in the LCIA phase (Table 2). Regarding the environmental mechanisms and damage pathways, midpoint (problem-oriented) impact categories were adopted in all the articles. Impact assessment at endpoint (damage-oriented) level was not performed in any of the articles.

The frequency of the environmental impact categories selected, however, differed considerably among the reviewed articles. Only climate change, with a characterization factor of global warming potential, was adopted as an impact category in all twelve studies. In fact, three reviewed articles $[56,62,64]$ addressed only the category of climate change. Four impact categories were considered in more than half of the twelve articles, namely terrestrial acidification (eight articles), photochemical oxidant formation (seven articles), ozone depletion (six articles) and mineral depletion (six articles). The categories of fossil depletion, cumulative energy demand and human toxicity were addressed in five studies. Moreover, eutrophication was considered in ten studies: in the form of freshwater eutrophication (five articles), marine eutrophication (three articles), or the total eutrophication potential in all recipients (two articles). Other impact categories, such as particulate matter formation, ecotoxicity (terrestrial, freshwater and marine) and ionizing radiation, were less frequently addressed in the reviewed studies. Surprisingly, little consideration was given to the impact on land use (agricultural, urban and natural land occupation), which is important in building construction, but was considered only in one article.

It is interesting to note that a number of the reviewed articles did not clearly describe the impact assessment method(s) employed. This applied to the case of developed methods and the authors' own 
methodology. One notable example is the ReCiPe 2008 method used in three articles. One article [61] specified the selection of the hierarchist perspective, while the other two $[54,58]$ did not state which ReCiPe perspective was chosen for characterization modelling. The ReCiPe 2008 methodology [66] includes three perspectives for grouping similar types of assumptions and choices, i.e., the individualist (based on the short-term interest), the hierarchist (based on the most common policy principle), and the egalitarian (the most precautionary perspective). In the case of characterization factors for climate change, for instance, the three ReCiPe perspectives represent different time horizons: 20 years for the individualist, 100 years for the hierarchist, and 500 years for the egalitarian.

Table 2. Impact categories and impact assessment methods used in the reviewed articles.

\begin{tabular}{|c|c|c|c|}
\hline Impact Category & $\begin{array}{l}\text { Spatial Scale } \\
\text { of Impact }\end{array}$ & $\begin{array}{l}\text { Frequency of } \\
\text { Selection }\end{array}$ & $\begin{array}{c}\text { Reviewed Articles } \\
\text { (Impact Assessment Method) }^{1}\end{array}$ \\
\hline Climate change & Global & 12 & $\begin{array}{c}\text { [53] (ILCD 2011); [54,58,61] (ReCiPe 2008); } \\
\text { [63] (ReCiPe 2016); [55] (CML 2001); } \\
\text { [56,57,59,60,62,64] (own methodology) }\end{array}$ \\
\hline Terrestrial acidification & Regional & 8 & $\begin{array}{c}\text { [53] (ILCD 2011); [54,58,61] (ReCiPe 2008); } \\
\text { [55] (CML 2001); [63] (ReCiPe 2016); } \\
\text { [59,60] (own methodology); }\end{array}$ \\
\hline $\begin{array}{l}\text { Photochemical oxidant } \\
\text { formation }\end{array}$ & Regional/local & 7 & $\begin{array}{c}\text { [53] (ILCD 2011); [54,58,61] (ReCiPe 2008); } \\
\text { [55] (CML 2001); [60] (own methodology); } \\
\text { [63] (ReCiPe 2016) }\end{array}$ \\
\hline Ozone depletion & Global & 6 & $\begin{array}{l}\text { [53] (ILCD 2011); [54,58,61] (ReCiPe 2008); } \\
\text { [55] (CML 2001); [63] (ReCiPe 2016) }\end{array}$ \\
\hline Mineral depletion & Global & 6 & $\begin{array}{l}\text { [53] (ILCD 2011); [54,58,61] (ReCiPe 2008); } \\
\text { [63] (ReCiPe 2016); [55] (CML 2001) }\end{array}$ \\
\hline Fossil depletion & Global & 5 & $\begin{array}{c}\text { [54,58,61] (ReCiPe 2008); [55] (CML 2001); } \\
\text { [63] (ReCiPe 2016) }\end{array}$ \\
\hline Cumulative energy demand & Global & 5 & $\begin{array}{c}\text { [53] (CED v1.08 in SimaPro v8.0.2); [57,59] } \\
\text { (own methodology); [61,63] (unspecified } \\
\text { CED version in SimaPro) }\end{array}$ \\
\hline Human toxicity & Local & 5 & $\begin{array}{l}\text { [53] (ILCD 2011); [54,58] (ReCiPe 2008); } \\
\text { [55] (CML 2001); [60] (own methodology) }\end{array}$ \\
\hline Freshwater eutrophication & Regional/local & 5 & $\begin{array}{c}\text { [53] (ILCD 2011); [54,58,61] (ReCiPe 2008); } \\
\text { [63] (ReCiPe 2016) }\end{array}$ \\
\hline Marine eutrophication & Regional/local & 3 & [53] (ILCD 2011); [54,58] (ReCiPe 2008); \\
\hline Eutrophication $^{2}$ & Regional/local & 2 & [55] (CML 2001); [60] (own methodology) \\
\hline Water depletion & Regional/local & 2 & {$[54,58](\operatorname{ReCiPe} 2008)$} \\
\hline Particulate matter formation & Local & 2 & {$[54,58](\operatorname{ReCiPe} 2008)$} \\
\hline Terrestrial ecotoxicity & Local & 2 & {$[54,58](\operatorname{ReCiPe} 2008)$} \\
\hline Freshwater ecotoxicity & Local & 2 & {$[54,58](\operatorname{ReCiPe} 2008)$} \\
\hline Marine ecotoxicity & Local & 2 & {$[54,58](\operatorname{ReCiPe} 2008)$} \\
\hline Ionizing radiation & Local & 2 & {$[54,58](\operatorname{ReCiPe} 2008)$} \\
\hline Agricultural land occupation & Local & 1 & [54] (ReCiPe 2008) \\
\hline Urban land occupation & Local & 1 & [54] (ReCiPe 2008) \\
\hline Natural land transformation & Local & 1 & [54] (ReCiPe 2008) \\
\hline
\end{tabular}

${ }^{1}$ References to impact methods: (ReCiPe 2008) [66], (ILCD 2011) [67], (CML 2001) [68], (ReCiPe 2016) [69]. ${ }^{2}$ Refers to the total potential eutrophication of all recipients (terrestrial, marine and freshwater) [70].

Another example of unclear descriptions of the impact assessment methods is the cumulative energy demand (CED). Among the five articles adopting the CED impact category, one [53] referred to the CED v1.08 method implemented in SimaPro v8.0.2. Two articles [61,63] did not specify which version of the CED method was used (in SimaPro v8.2.3.0 and v8.4.0.0, respectively). The last two articles [57,59], in which the authors used their own methodology, presented a brief description of the equation used in the calculations (i.e., multiplying the total mass of a material by the unit value of the material). Furthermore, none of the five studies referred to above clarified the CED method employed in any detail. For example, the CED method may refer to CED standard (implemented in the Ecoinvent database, with higher heating value, etc.), CED energy statistics (with the lower heating value of fossil and renewable fuels, etc.), CED uranium low or CED uranium high [71]. 


\subsection{Interpretation}

All the articles reviewed presented results of contribution or dominance analysis from LCIA. However, a comprehensive set of sensitivity analyses, as required by ISO 14044, was performed only in a few of the studies. The sensitivity of the results, by means of scenario analyses, was analysed in three articles: with respect to dynamic load tests for CDF [63], alternative designs of CSF [61], and transport-, machine- and material-related scenarios for foundation construction [62]. Another three articles discussed uncertainties in a qualitative way, regarding generalizability and localization-related uncertainties in a comparative LCA [58], preciseness of the LCIA results [54], and data quality in terms of geographical representativeness [57]. However, no uncertainty analysis was performed in a quantitative way, for example, using the widely used Monte Carlo method [72] to calculate the uncertainty of the LCA results, in any of the articles. It should also be noted that neither sensitivity analysis nor uncertainty analysis was reported in any of the other six articles.

\section{Discussion and Recommendations}

\subsection{Application of LCA in Support of Sustainable Geotechnical Design and Construction for Buildings}

The development of region-specific LCI databases, with representative data for construction products and geotechnical works, is crucial in the application of LCA for decision support in building construction at specific sites. According to a review of LCA databases for construction materials [20], only a few contained LCI data on construction materials, among which Ecoinvent and the GaBi Database stood out due to their integrity, usability and dedicated resources. This is exemplified in a study on LCA of two Finnish residential buildings [58], based on the Ecoinvent database v3.0 in SimaPro software v8.0, and GaBi Database v6.1 in GaBi software v6.4, respectively. The authors reported substantial differences in the results of the selected fifteen ReCiPe 2008 midpoint impact categories, largely due to the differences in production processes of building materials and predefined characterization factors between different databases [58]. This indicates the necessity for good documentation of all sources of uncertainty inherent in LCI and LCIA, regarding the quality of existing LCI databases, treatment of missing data, and the choice of impact categories and impact assessment methods, etc. In the case of geotechnical LCA studies using non-location-specific inventory data and emission factors, the LCA results must be interpreted with caution, especially when making comparisons and for decision-making purposes.

When an LCA study is performed for decision support, caution should be exercised when adopting a single indicator of environmental sustainability, such as the carbon footprint or embodied energy. In an LCA study, the choice of impact categories should reflect a comprehensive set of environmental issues related to the product system being studied and the defined goal and scope [8]. Although ISO 14044 does not specify which impact assessment methods should be applied by LCA practitioners, they should be of international scientific acceptance [73]. The EN 15978 standard gives a list of indicators for the environmental performance of buildings, including seven indicators of environmental impact, eight indicators of resource use and seven indicators of waste categories and outflows [45]. However, assessment of the impact on land use has not yet been afforded enough attention in either EN 15978 or in most of the published building LCA studies. In a recent review on the use of impact categories for LCA of geotechnical systems [74], the necessity of further development or refinement of environmental indicators, impact categories and cause-effect pathways was emphasized. In particular, the authors highlighted the need for LCA of geotechnical applications related to soil function, soil quality and ecosystems services [75].

There is a need to perform comprehensive environmental assessment with multi-impact categories in LCAs of geotechnical construction works for buildings, to help avoid problem shifting spatially and between impact categories. As can be seen from the twelve articles reviewed in this study (Table 2), some categories are rarely or less frequently considered. As mentioned above, three of the reviewed articles $[56,62,64]$ considered only climate change (expressed as GHG or carbon footprint) in relation 
to the direct and indirect use of fossil fuels and electricity. Although the carbon footprint is often employed in simplified LCA studies and has become popular among decision-makers in industry and politics, opinions are still divided regarding the representativeness of the carbon footprint as a general environmental performance indicator. Based on the results of LCA of about 4000 different products, Laurent et al. [76] concluded that the carbon footprint was a poor reflection of the environmental burden resulting from the emission of toxic substances, as in the case when shifting electricity production from fossil-based to renewable-based fuels. In an LCA of the pre-use phase of a multi-storey residential building in Finland [54], the authors employed the ReCiPe 2008 midpoint method and reported that the impact on climate change was strongly correlated to eight impact categories (ozone depletion, terrestrial acidification, marine eutrophication, photochemical oxidant formation, particulate matter formation, ionizing radiation, water depletion, and fossil depletion). By contrast, the authors reported a weak correlation between climate change and the other nine impact categories (human toxicity, freshwater ecotoxicity, terrestrial ecotoxicity, marine ecotoxicity, freshwater eutrophication, natural land transformation, urban land occupation, agricultural land occupation, and metal depletion) [54].

A shift from retrospective to prospective LCAs is needed to ensure more sustainable geotechnical design and construction practices in a proactive way. Retrospective LCAs were carried out in most of the studies reviewed here, either in later stages of the design process, or based on completed construction projects. Retrospective LCAs can be used to describe the environmental impacts of buildings and to identify environmental hotspots, but they contribute little or nothing to improving the environmental performance of building construction. Rather, prospective LCAs should be performed in earlier stages of the geotechnical and architectural design processes, in order to influence building design towards more environmentally friendly building construction. As a step towards prospective LCAs, several recent publications have described the integration of LCA and building information modelling (BIM) in the early building design stage [77-79]. BIM-based LCA is often regarded as having the potential to reduce the time and effort required for data collection in building LCA studies [79]. However, in a recent evaluation of BIM-based LCA results from the design of a real office building in Switzerland, Hollberg et al. [77] reported that the embodied global warming potential during the design phase was twice that in the final building. The authors stated that "a BIM-based environmental assessment during the design process could be misleading and counterproductive" [77]. In future research, it would be interesting to investigate the extent to which prospective LCAs can contribute to more sustainable design and geotechnical construction works for buildings.

\subsection{A Conceptual Model for LCA of Geotechnical Works in Building Construction}

At the time of writing, no building LCA studies had been published, presenting a conceptualization of geotechnical works for buildings. Most of the previously published LCA studies on building foundations have focused primarily on construction products and/or the use of equipment/machinery, while geotechnical works are often simplified or even neglected. As emphasized by Kendall et al. [44], there is currently no established framework for conducting LCA in the field of geotechnical engineering. According to EN 15978, the system boundary of the construction-installation process (module A5) should include a variety of processes. Examples of processes are ground works and landscaping, transport (of materials, products, waste and equipment within the site), storage of products, temporary works, on-site production and transformation of a product, and installation of the products in the building [45]. However, EN 15978 does not describe geotechnical works in any detail, leaving room for interpretation in the choice of system boundaries and unit processes for LCAs of geotechnical works for building construction.

In an effort to support the application of LCA to geotechnical works in building construction, we developed a conceptual model intended to provide a systematic demonstration of inventory flows and system boundaries (Figure 3). Employing a cradle-to-site system boundary, this conceptual model covers both background and foreground systems. In short, the background system represents cradle-to-gate unit processes, such as manufacturing of materials, fuel production and electricity 
generation. The foreground system is exemplified by five processes (with examples of on-site activities) related to geotechnical works, including: (i) site investigation (e.g., probing, sampling and laboratory testing), (ii) earthworks at the early stage of geotechnical works (e.g., clearing/grubbing and excavation), (iii) ground improvement (e.g., deep mixing and compaction), (iv) foundations (e.g., shallow, deep or hybrid foundation construction), and (iv) earthworks in the final stage of geotechnical work (e.g., earth retaining structures and backfill).

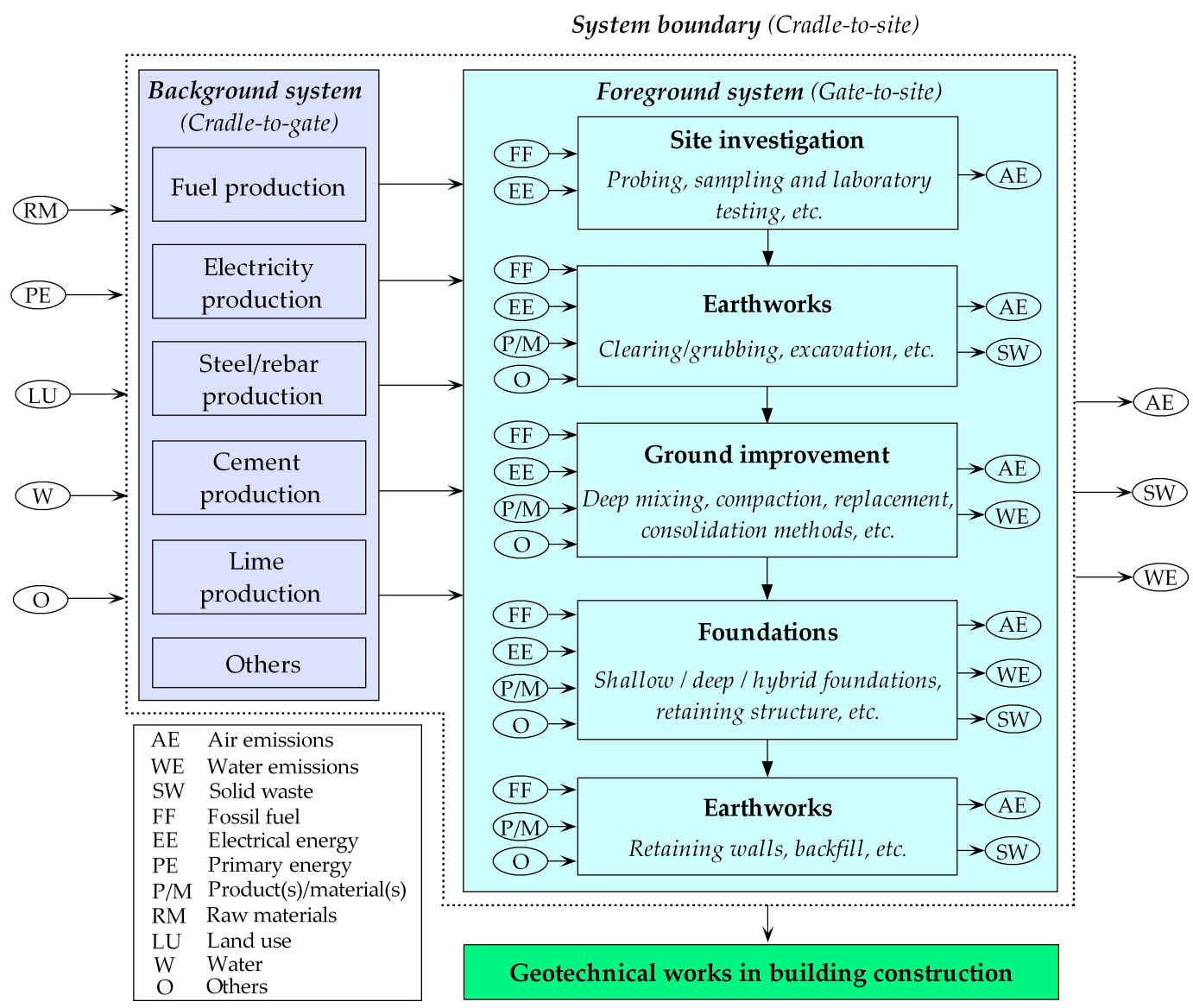

Figure 3. A conceptual model intended to demonstrate inventory flows and system boundaries, to support the definition of scope in LCA of geotechnical works in building construction.

In practice, the suggested conceptual model can serve as a basis for performing three types of LCA studies with different levels of detail. The first is the unit process level, aiming to identify environmental hotspots resulting from a single unit process, or to identify a more environmentally friendly choice between alternative methods of, for example, soil improvement and ground modification. The second level is the building construction stage, aiming to assess the environmental performance of geotechnical works and identify relevant environmental hotspots. The third level is the complete life cycle of the building, e.g., focusing on identifying the contribution of geotechnical construction works to the total potential environmental impact of a building throughout its life cycle. It is important to use a consistent functional unit in all three types of LCA studies that applies to all the relevant unit processes and various stages of the building's life cycle. For the sake of clarity and comparison purposes, the functional unit should be defined in a harmonized way in future building LCA studies, if possible, using terms in existing standards or codes. For instance, several terms in building construction have been clearly defined by the European Commission's Office for Infrastructure and Logistics in Brussels in the document "Measuring Code", including "gross floor area", "net floor area", "usable area" and "construction area" [80]. 
LCA of geotechnical works in building construction has several distinctive features, which are summarized as follows. Firstly, the design of building foundations and other geotechnical works is on a case-by-case basis, depending on the load of the superstructure, site-specific soil properties and mechanisms, etc. LCA practitioners must thus exercise caution in applying simplifications and assumptions based on geotechnical works in building construction at other locations. Secondly, attention needs be paid to the differences in the expected lifespan of buildings and building foundations. A lifespan of 50-100 years is assumed for buildings in most of the literature on LCA [14,17,81]. In the case of building foundations, a 50-year lifespan was assumed for shallow and deep foundations in two of LCA studies reviewed here [61,63]. According to Pujadas-Gispert et al. [63], well-designed foundations need neither maintenance nor repair, and usually remain underground at the end of their lifespan. However, we suggest that sensitivity analyses should be carried out in relation to lifespan, especially for LCAs on the whole life cycle of buildings. Thirdly, on-site emissions from construction activities occur during a relatively short period. This indicates the necessity to carry out spatially differentiated impact assessment of various emissions, taking site-dependent conditions into consideration.

This conceptual model can facilitate effective communication and cooperation between LCA practitioners, foundation designers, geotechnical engineers, decision-makers and other stakeholders, concerning the application of geotechnical LCAs in the construction and civil engineering sector. LCA practitioners and geotechnical (or geoenvironmental) engineers need to cooperate effectively when performing geotechnical LCAs to support planning and decision-making, and they should preferably be involved at an earlier stage in the planning of a construction project. It would be beneficial for geotechnical and geoenvironmental engineers with very little experience of LCA to have a basic understanding of the theoretical framework of LCA. LCA practitioners, on the other hand, should become familiar with relevant geotechnical construction works and improve their knowledge on soil science and geotechnical engineering. In this way, LCA practitioners can better identify inflows and outflows of relevant unit processes, and to ensure accurate and detailed interpretation of the results of an LCA study.

\section{Conclusions}

- Based on the literature review, it is concluded that there is a need for more detailed and harmonized LCA studies of geotechnical works in building construction, conforming to relevant standards for LCA and sustainability of construction works. The results of the present study show that there are noticeable discrepancies in the recent literature on LCA of buildings including foundations, especially regarding functional units, system boundaries, impact categories, and uncertainty/sensitivity analysis of LCA results. This makes it difficult to compare the results of LCA and use them to aid environmental decision-making in building construction.

- LCA-based environmental assessment of geotechnical construction works for buildings is still in its infancy and there is a need for a harmonized framework to guide LCA of geotechnical works. With this paper, a first step is taken by (i) defining the system boundary of geotechnical works in building construction, and (ii) proposing a conceptual model for LCA of geotechnical works, focusing on the demonstration of inventory flows and system boundaries. This conceptual model is designed to support the scope definition in LCA of geotechnical construction works for buildings. It can also serve as a basis for communication and cooperation between geotechnical engineers, foundation designers, LCA practitioners, decision-makers and other stakeholders. Future work will involve the application and validation of the proposed conceptual model in specific case studies both in Sweden and abroad.

- It is evident from the literature review that future research ought to focus on improving LCI databases for geotechnical works, addressing construction-specific environmental impacts in LCIA, and developing comprehensive guidelines for LCA of geotechnical works in the construction and civil engineering sector. 
Author Contributions: Conceptualization, X.S., C.C., R.K., D.B. and H.K.; methodology, X.S., D.B., H.K., C.C. and R.K.; writing — original draft preparation, X.S.; writing—review and editing, D.B., H.K., C.C., R.K. and X.S. All authors have read and agreed to the published version of the manuscript.

Funding: This research received no external funding.

Conflicts of Interest: The authors declare no conflict of interest.

\section{References}

1. European Commission. COM(2011) 571 Final, Roadmap to a Resource Efficient Europe-Turning Waste into a Resource; European Commission: Brussels, Belgium, 2011.

2. European Commission. COM(2011) 112 Final, A Roadmap for Moving to a Competitive Low Carbon Economy in 2050; European Commission: Brussels, Belgium, 2011.

3. European Commission. COM(2018) 773 Final, A Clean Planet for All. A European Strategic Long-Term Vision for a Prosperous, Modern, Competitive and Climate Neutral Economy; European Commission: Brussels, Belgium, 2018.

4. European Commission. EUCO 29/19, European Council Meeting (12 December 2019)—Conclusions; European Commission: Brussels, Belgium, 2019.

5. Ministry of the Environment and Energy. The Swedish Climate Policy Framework; Government Offices of Sweden: Stockholm, Sweden, 2017.

6. Fossil Free Sweden. Roadmap for Fossil-Free Competitiveness: Construction and Civil Engineering Sector; Fossil Free Sweden: Stockholm, Sweden, 2018.

7. ISO (International Organization for Standardization). ISO 14040: Environmental Management-Life Cycle Assessment-Principles and Framework; ISO: Geneva, Switzerland, 2006.

8. ISO (International Organization for Standardization). ISO 14044: Environmental Management-Life Cycle Assessment-Requirements and Guidelines; ISO: Geneva, Switzerland, 2006.

9. AFNOR Normalisation. Standards Overview. Available online: http://portailgroupe.afnor.fr/public espacenormalisation/CENTC350/standards_overview.html (accessed on 27 November 2019).

10. Anand, C.K.; Amor, B. Recent developments, future challenges and new research directions in LCA of buildings: A critical review. Renew. Sustain. Energy Rev. 2017, 67, 408-416. [CrossRef]

11. Peng, C. Calculation of a building's life cycle carbon emissions based on Ecotect and building information modeling. J. Clean. Prod. 2016, 112, 453-465. [CrossRef]

12. Serrano, A.Á.R.; Álvarez, S.P. Life cycle assessment in building: A case study on the energy and emissions impact related to the choice of housing typologies and construction process in Spain. Sustainability 2016, 8, 287. [CrossRef]

13. Wu, H.J.; Yuan, Z.W.; Zhang, L.; Bi, J. Life cycle energy consumption and $\mathrm{CO}_{2}$ emission of an office building in China. Int. J. Life Cycle Assess. 2012, 17, 105-118. [CrossRef]

14. Ding, G.K.C. Life cycle assessment in buildings: An overview of methodological approach. In Encyclopedia of Renewable and Sustainable Materials, 1st ed.; Hashmi, S., Choudhury, I.A., Eds.; Elsevier: Amsterdam, The Netherlands, 2020; Volume 4, pp. 462-475.

15. Ortiz, O.; Pasqualino, J.C.; Díez, G.; Castells, F. The environmental impact of the construction phase: An application to composite walls from a life cycle perspective. Resour. Conserv. Recycl. 2010, 54, 832-840. [CrossRef]

16. Weißenberger, M.; Jensch, W.; Lang, W. The convergence of life cycle assessment and nearly zero-energy buildings: The case of Germany. Energy Build. 2014, 76, 551-557. [CrossRef]

17. Buyle, M.; Braet, J.; Audenaert, A. Life cycle assessment in the construction sector: A review. Renew. Sustain. Energy Rev. 2013, 26, 379-388. [CrossRef]

18. Gervasio, H.; Dimova, S. Model for Life Cycle Assessment (LCA) of Buildings; Publications Office of the European Union: Luxembourg, 2018.

19. Nadoushani, Z.S.M.; Akbarnezhad, A. Effects of structural system on the life cycle carbon footprint of buildings. Energy Build. 2015, 102, 337-346. [CrossRef]

20. Martínez-Rocamora, A.; Solís-Guzmán, J.; Marrero, M. LCA databases focused on construction materials: A review. Renew. Sustain. Energy Rev. 2016, 58, 565-573. [CrossRef] 
21. Kylili, A.; Fokaides, P.A.; Seduikyte, L. Sustainability tools for the assessment of construction materials and buildings. J. Sustain. Archit. Civ. Eng. 2016, 16, 61-69. [CrossRef]

22. Pradhan, S.; Tiwari, B.R.; Kumar, S.; Barai, S.V. Comparative LCA of recycled and natural aggregate concrete using Particle Packing Method and conventional method of design mix. J. Clean. Prod. 2019, 228, 679-691. [CrossRef]

23. Vieira, D.R.; Calmon, J.L.; Coelho, F.Z. Life cycle assessment (LCA) applied to the manufacturing of common and ecological concrete: A review. Constr. Build. Mater. 2016, 124, 656-666. [CrossRef]

24. Lee, J.; Tae, S.; Kim, R. A Study on the analysis of $\mathrm{CO}_{2}$ emissions of apartment housing in the construction process. Sustainability 2018, 10, 365. [CrossRef]

25. Giesekam, J.; Barrett, J.; Taylor, P. Scenario analysis of embodied greenhouse gas emissions in UK construction. Proc. Inst. Civ. Eng. Eng. Sustain. 2018, 171, 178-190. [CrossRef]

26. Azari, R.; Abbasabadi, N. Embodied energy of buildings: A review of data, methods, challenges, and research trends. Energy Build. 2018, 168, 225-235. [CrossRef]

27. Jia Wen, T.; Siong, H.C.; Noor, Z.Z. Assessment of embodied energy and global warming potential of building construction using life cycle analysis approach: Case studies of residential buildings in Iskandar Malaysia. Energy Build. 2015, 93, 295-302. [CrossRef]

28. Gan, V.J.L.; Chan, C.M.; Tse, K.T.; Lo, I.M.C.; Cheng, J.C.P. A comparative analysis of embodied carbon in high-rise buildings regarding different design parameters. J. Clean. Prod. 2017, 161, 663-675. [CrossRef]

29. Pomponi, F.; Moncaster, A. Scrutinising embodied carbon in buildings: The next performance gap made manifest. Renew. Sustain. Energy Rev. 2018, 81, 2431-2442. [CrossRef]

30. Diakaki, C.; Kolokotsa, D. Life cycle assessment of buildings. In A Handbook of Sustainable Building Design and Engineering: An Integrated Approach to Energy, Health and Operational Performance; Mumovic, D., Santamouris, M., Eds.; Routledge: New York, NY, USA, 2019; pp. 151-168.

31. Goldstein, B.; Rasmussen, F.N. LCA of buildings and the built environment. In Life Cycle Assessment: Theory and Practice; Hauschild, M.Z., Rosenbaum, R.K., Olsen, S.I., Eds.; Springer International Publishing AG: Cham, Switzerland, 2018; pp. 695-722.

32. Inui, T.; Chau, C.; Soga, K.; Nicolson, D.; O'Riordan, N. Embodied energy and gas emissions of retaining wall structures. J. Geotech. Geoenviron. Eng. 2011, 137, 958-967. [CrossRef]

33. Pons, J.J.; Penadés-Plà, V.; Yepes, V.; Martí, J.V. Life cycle assessment of earth-retaining walls: An environmental comparison. J. Clean. Prod. 2018, 192, 411-420. [CrossRef]

34. Damians, I.P.; Bathurst, R.J.; Adroguer, E.G.; Josa, A.; Lloret, A. Environmental assessment of earth retaining wall structures. Environ. Geotech. 2017, 4, 415-431. [CrossRef]

35. Shillaber, C.M.; Mitchell, J.K.; Dove, J.E. Energy and carbon assessment of ground improvement works. I: Definitions and background. J. Geotech. Geoenviron. Eng. 2015, 142, 04015083. [CrossRef]

36. Shillaber, C.M.; Mitchell, J.K.; Dove, J.E. Energy and carbon assessment of ground improvement works. II: Working model and example. J. Geotech. Geoenviron. Eng. 2015, 142, 04015084. [CrossRef]

37. Da Rocha, C.G.; Passuello, A.; Consoli, N.C.; Samaniego, R.A.Q.; Kanazawa, N.M. Life cycle assessment for soil stabilization dosages: A study for the Paraguayan Chaco. J. Clean. Prod. 2016, 139, 309-318. [CrossRef]

38. Forsythe, P.; Ding, G. Greenhouse gas emissions from excavation on residential construction sites. Australas. J. Constr. Econ. Build. 2014, 14,1-10. [CrossRef]

39. Misra, A.; Basu, D. A quantitative sustainability indicator system for pile foundations. In Proceedings of the GeoCongress 2012, Oakland, CA, USA, 25-29 March 2012; pp. 4252-4261.

40. Giri, R.K.; Reddy, K.R. LCA and sustainability assessment for selecting deep foundation system for high-rise buildings. In Proceedings of the ICSI 2014: Creating Infrastructure for a Sustainable World, Long Beach, CA, USA, 6-8 November 2014; Crittenden, J., Hendrickson, C., Wallace, B., Eds.; American Society of Civil Engineers: Reston, VA, USA, 2014; pp. 621-630.

41. Ay-Eldeen, M.K.; Negm, A.M. Global warming potential impact due to pile foundation construction using life cycle assessment. Electron. J. Geotech. Eng. 2015, 20, 4413-4421.

42. Basu, D.; Misra, A.; Puppala, A.J. Sustainability and geotechnical engineering: Perspectives and review. Can. Geotech. J. 2015, 52, 96-113. [CrossRef]

43. Reddy, K.R.; Kumar, G. Addressing sustainable technologies in geotechnical and geoenvironmental engineering. In Geotechnics for Natural and Engineered Sustainable Technologies; Krishna, A.M., Dey, A., Sreedeep, S., Eds.; Springer: Singapore, 2018; pp. 1-26. 
44. Kendall, A.; Raymond, A.J.; Tipton, J.; DeJong, J.T. Review of life-cycle-based environmental assessments of geotechnical systems. Eng. Sustain. 2016, 171, 57-67. [CrossRef]

45. European Committee for Standardization. EN 15978:2011 Sustainability of Construction Works-Assessment of Environmental Performance of Buildings-Calculation Method; European Committee for Standardization: Brussels, Belgium, 2011.

46. Burland, J.; Chapman, T.; Skinner, H.; Brown, M. ICE Manual of Geotechnical Engineering, Volume 1: Geotechnical Engineering Principles, Problematic Soils and Site Investigation; ICE Publishing: London, UK, 2012.

47. Burland, J.; Chapman, T.; Skinner, H.; Brown, M. ICE Manual of Geotechnical Engineering, Volume 2: Geotechnical Design, Construction and Verification; ICE Publishing: London, UK, 2012.

48. CEN (European Committee for Standardization). European Standard EN 1997. Eurocode 7. Geotechnical Design; CEN: Brussels, Belgium, 2002.

49. ISO (International Organization for Standardization). ISO 6707-1:2017 Buildings and Civil Engineering Works_Vocabulary_Part 1: General Terms; ISO: Geneva, Switzerland, 2017.

50. Bjørn, A.; Owsianiak, M.; Laurent, A.; Olsen, S.I.; Corona, A.; Hauschild, M.Z. Scope definition. In Life Cycle Assessment: Theory and Practice; Hauschild, M.Z., Rosenbaum, R.K., Olsen, S.I., Eds.; Springer International Publishing AG: Cham, Switzerland, 2018; pp. 75-116.

51. Walter, K.; Grahl, B. Life Cycle Assessment (LCA): A Guide to Best Practice; Wiley-VCH: Weinheim, Germany, 2014.

52. European Commission-Joint Research Centre-Institute for Environment and Sustainability. International Reference Life Cycle Data System (ILCD) Handbook—General Guide for Life Cycle Assessment_Detailed Guidance; Publications Office of the European Union: Luxembourg, 2010.

53. Evangelista, P.P.A.; Kiperstok, A.; Torres, E.A.; Gonçalves, J.P. Environmental performance analysis of residential buildings in Brazil using life cycle assessment (LCA). Constr. Build. Mater. 2018, 169, 748-761. [CrossRef]

54. Heinonen, J.; Säynäjoki, A.; Junnonen, J.M.; Pöyry, A.; Junnila, S. Pre-use phase LCA of a multi-story residential building: Can greenhouse gas emissions be used as a more general environmental performance indicator? Build. Environ. 2016, 95, 116-125. [CrossRef]

55. Kylili, A.; Ilic, M.; Fokaides, P.A. Whole-building Life Cycle Assessment (LCA) of a passive house of the sub-tropical climatic zone. Resour. Conserv. Recycl. 2017, 116, 169-177. [CrossRef]

56. Li, L.; Chen, K. Quantitative assessment of carbon dioxide emissions in construction projects: A case study in Shenzhen. J. Clean. Prod. 2017, 141, 394-408. [CrossRef]

57. Kumanayake, R.P.; Luo, H. Cradle-to-gate life cycle assessment of energy and carbon of a residential building in Sri Lanka. J. Natl. Sci. Found. Sri Lanka 2018, 46, 355-367. [CrossRef]

58. Emami, N.; Heinonen, J.; Marteinsson, B.; Säynäjoki, A.; Junnonen, J.M.; Laine, J.; Junnila, S. A life cycle assessment of two residential buildings using two different LCA database-software combinations: Recognizing uniformities and inconsistencies. Buildings 2019, 9, 20. [CrossRef]

59. Ondova, M.; Estokova, A. Environmental impact assessment of building foundation in masonry family houses related to the total used building materials. Environ. Prog. Sustain. Energy 2016, 35, 1113-1120. [CrossRef]

60. Sandanayake, M.; Zhang, G.; Setunge, S. Environmental emissions at foundation construction stage of buildings-Two case studies. Build. Environ. 2016, 95, 189-198. [CrossRef]

61. Pujadas-Gispert, E.; Sanjuan-Delmás, D.; Josa, A. Environmental analysis of building shallow foundations: The influence of prefabrication, typology, and structural design codes. J. Clean. Prod. 2018, 186, 407-417. [CrossRef]

62. Luo, W.; Sandanayake, M.; Zhang, G. Direct and indirect carbon emissions in foundation construction-Two case studies of driven precast and cast-in-situ piles. J. Clean. Prod. 2019, 211, 1517-1526. [CrossRef]

63. Pujadas-Gispert, E.; Sanjuan-Delmás, D.; de la Fuente, A.; Moonen, S.P.G.; Josa, A. Environmental analysis of concrete deep foundations: Influence of prefabrication, concrete strength, and design codes. J. Clean. Prod. 2020, 244, 118751. [CrossRef]

64. Li, X.J.; Zheng, Y.D. Using LCA to research carbon footprint for precast concrete piles during the building construction stage: A China study. J. Clean. Prod. 2020, 245, 118754. [CrossRef]

65. Curran, M.A. Overview of goal and scope definition in life cycle assessment. In Goal and Scope Definition in Life Cycle Assessment; Curran, M.A., Ed.; Springer: Dordrecht, The Netherlands, 2017; pp. 1-62. 
66. Goedkoop, M.; Heijungs, R.; Huijbregts, M.; Schryver, A.D.; Struijs, J.; van Zelm, R. ReCiPe 2008: A Life Cycle Impact Assessment Method which Comprises Harmonised Category Indicators at the Midpoint and the Endpoint Level. Report I: Characterisation; Ministry of Ministry of Housing, Spatial Planning and Environment: The Hague, The Netherlands, 2013.

67. European Commission-Joint Research Centre-Institute for Environment and Sustainability. Characterisation Factors of the ILCD Recommended Life Cycle Impact Assessment Methods. Database and Supporting Information; Publications Office of the European Union: Luxembourg, 2012.

68. CML. CML's Impact Assessment Methods and Characterisation Factors; Institute of Environmental Sciences (CML), Leiden University: Leiden, The Netherlands, 2001.

69. Huijbregts, M.A.J.; Steinmann, Z.J.N.; Elshout, P.M.F.; Stam, G.; Verones, F.; Vieira, M.D.M.; Hollander, A.; Zijp, M.; van Zelm, R. ReCiPe 2016: A Harmonized Life Cycle Impact Assessment Method at Midpoint and Endpoint Level. Report I: Characterization; National Institute for Public Health and the Environment: Bilthoven, The Netherlands, 2016.

70. Henryson, K.; Hansson, P.A.; Sundberg, C. Spatially differentiated midpoint indicator for marine eutrophication of waterborne emissions in Sweden. Int. J. Life Cycle Assess. 2018, 23, 70-81. [CrossRef]

71. Frischknecht, R.; Wyss, F.; Knöpfel, S.B.; Lützkendorf, T.; Balouktsi, M. Cumulative energy demand in LCA: The energy harvested approach. Int. J. Life Cycle Assess. 2015, 20, 957-969. [CrossRef]

72. Heijungs, R. On the number of Monte Carlo runs in comparative probabilistic LCA. Int. J. Life Cycle Assess. 2020, 25, 394-402. [CrossRef]

73. Hauschild, M.Z.; Huijbregts, M.A.J. Introducing life cycle impact assessment. In Life Cycle Impact Assessment; Hauschild, M.Z., Huijbregts, M.A.J., Eds.; Springer: Dordrecht, The Netherlands, 2015; pp. 1-16.

74. Raymond, A.J.; Tipton, J.R.; Dejong, J.T. Review of impact categories and environmental indicators for life cycle assessment of geotechnical systems. J. Ind. Ecol. 2020, 24, 485-499. [CrossRef]

75. Laurent, A.; Olsen, S.I.; Hauschild, M.Z. Limitations of carbon footprint as indicator of environmental sustainability. Environ. Sci. Technol. 2012, 46, 4100-4108. [CrossRef] [PubMed]

76. Rezaei, F.; Bulle, C.; Lesage, P. Integrating building information modeling and life cycle assessment in the early and detailed building design stages. Build. Environ. 2019, 153, 158-167. [CrossRef]

77. Hollberg, A.; Genova, G.; Habert, G. Evaluation of BIM-based LCA results for building design. Autom. Constr. 2020, 109, 102972. [CrossRef]

78. Santos, R.; Costa, A.A.; Silvestre, J.D.; Pyl, L. Integration of LCA and LCC analysis within a BIM-based environment. Autom. Constr. 2019, 103, 127-149. [CrossRef]

79. Nwodo, M.N.; Anumba, C.J. A review of life cycle assessment of buildings using a systematic approach. Build. Environ. 2019, 162, 106290. [CrossRef]

80. Office for Infrastructure and Logistics of European Commission. Measuring Code; European Commission: Brussels, Belgium, 2009.

81. Cabeza, L.F.; Rincón, L.; Vilariño, V.; Pérez, G.; Castell, A. Life cycle assessment (LCA) and life cycle energy analysis (LCEA) of buildings and the building sector: A review. Renew. Sustain. Energy Rev. 2014, 26, 394-416. [CrossRef]

(C) 2020 by the authors. Licensee MDPI, Basel, Switzerland. This article is an open access article distributed under the terms and conditions of the Creative Commons Attribution (CC BY) license (http://creativecommons.org/licenses/by/4.0/). 